\title{
ANALISIS KOMPENSASI DAN MOTIVASI KERJA TERHADAP KEPUASAN KERJA PADA PT PLN (PERSERO) UNIT LAYANAN PELANGGAN DEPOK KOTA JAWA BARAT
}

\author{
Rani Kurniasari' $^{1)}$, Bilgah $^{2)}$, Amanda Dwi Shafira ${ }^{3)}$ \\ 1,3) Administrasi Bisnis Universitas Bina Sarana Informatika \\ ${ }^{2)}$ Sistem Informasi Universitas Bina Sarana Informatika \\ e-mail: ${ }^{1)}$ rani.rku@bsi.ac.id, ${ }^{2)}$ bilgah.bgh@bsi.ac.id, ${ }^{3)}$ amandadwi631@ gmail.com
}

\begin{abstract}
Abstrak
Setiap perusahaan menginginkan memiliki karyawan yang bagus. Karyawan yang bagus harus mendapat penghargaan dari perusahaan salah satunya dengan memberikan kompensasi yang baik. Selain kompensasi yang baik, karyawan juga harus diberikan motivasi agar dapat meningkatkan kepuasan bekerja dalam dirinya. Kerja keras dari karyawan harus di apresiasi salah satunya dengan memberikan kompensasi yang baik dan motivasi kerja oleh perusahaan. Hal ini sangat penting untuk diperhatikan bila menginginkan setiap karyawan dapat memberikan andil positif dan memiliki kepuasan dalam bekerja. Dengan demikian karyawan akan memiliki semangat yang tinggi dalam melaksanakan tugas dan tanggung jawabnya. Penelitian ini dilakukan terhadap karyawan PT PLN Unit Layanan Pelanggan Depok Kota Jawa Barat. Penelitian dilakukan dengan menyebar kuisioner pada seluruh karyawan. Hasil dari perhitungan kuiesioner menghasilkan nilai R square sebesar 0,812, yang mengindikasikan bahwa kepuasan kerja karyawan dipengaruhi oleh kompensasi dan motivasi kerja sebesar 81,2\% sedangkan sisanya 18,8\% dipengaruhi oleh faktor-faktor lain. Hasil persamaan regresi pada penelitian ini adalah $Y=-2.236+0,493 X 1+0,561 X 2+e$. Uji simultan juga dilakukan pada penelitian ini, dengan nilai $F$ test sebesar 103,824 yang signifikan pada 0.000. Artinya variabel independen kompensasi dan motivasi kerja secara simultan mempengaruhi variabel kepuasan kerja karyawan.
\end{abstract}

Kata Kunci: Kompensasi, Motivasi Kerja, Kepuasan Kerja

\begin{abstract}
Every company wants to have good employees. Good employees must get an award from the company one of them by giving good compensation. In addition to good compensation, employees must also be motivated to increase work satisfaction within themselves. The hard work of employees must be appreciated one of them by giving good compensation and work motivation by the company. This is very important to note if you want every employee to contribute positively and have satisfaction at work. Thus, employees will have a high enthusiasm in carrying out their duties and responsibilities. This research was conducted on the employees of PT PLN Depok West Java Customer Service Unit. The study was conducted by distributing questionnaires to all employees. The results of the questionnaire calculation produce an $R$ square value of 0.812 , which indicates that employee job satisfaction is influenced by compensation and work motivation by $81.2 \%$ while the remaining $18.8 \%$ is influenced by other factors. The results of the regression equation in this study are $Y=-$ $2,236+0,493 X 1+0,561 X 2+e$. Simultaneous tests were also carried out in this study, with an $F$ test value of 103.824 which was significant at 0.000. This means that the independent variable compensation and work motivation simultaneously affect the variable employee satisfaction.
\end{abstract}

\section{Keywords: Compensation, Work Motivation, Job Satisfaction}

\section{PENDAHULUAN}

Sebuah organisasi pada dasarnya terdiri dari berbagai macam individu yang berasal dari berbagai status sosial yang berbeda. Individu individu itulah yang akan menjadi motor penggerak sumber daya manusia dari sebuah kegiatan. Kepuasan kerja merupakan perasaan seseorang terhadap pekerjaannya. Ini berarti bahwa konsepsi kepuasan kerja melihatnya sebagai hasil interaksi manusia terhadap lingkungan pekerjaannya. Selain itu kepuasan kerja juga mempengaruhi sikap atau perasaan karyawan terhadap aspek-aspek yang menyenangkan atau tidak menyenangkan mengenai pekerjaan yang sesuai dengan penilaian masing-masing karyawan pada perusahaan tersebut.

Motivasi merupakan hal yang sangat penting untuk diperhatikan oleh pihak perusahaan bila menginginkan setiap karyawan dapat 
memberikan andil positif terhadap pencapaian tujuan perusahaan, karena dengan motivasi seseorang karyawan akan memiliki semangat yang tinggi dalam melaksanakan tugas dan tanggung jawabnya. Pentingnya motivasi adalah karena motivasi merupakan perilaku manusia supaya mau bekerja giat dan antusias mencapai hasil yang maksimal diantaranya seperti seleksi karir untuk jenjang yang lebih tinggi serta program reward untuk karyawan berprestasi di perusahaan. Kompensasi merupakan imbalan yang diterima oleh karyawan dari hasil kerja yang dilakukan. Bentuk dari kompensasi ada yang langsung dan tidak langsung. Dengan adanya kompensasi yang baik dapat lebih menyemangati karyawan dalam bekerja. Dengan adanya kompensasi yang baik dan motivasi kerja yang bai, maka kepuasan kerja karyawan dapat dicapai.

Pada penelitian ini PT PLN (Persero) Unit Layanan Pelanggan Depok Kota Jawa Barat menjadi objek penelitian. Yang menjadi rumusan masalah pada penelitian ini adalah (1)Apakah ada pengaruh yang signifikan Antara kompensasi terhadap kepuasan kerja pada karyawan, (2)Apakah ada pengaruh antar motivasi kerja karyawan terhadap kepuasan kerja karyawan. Penulis mlaukan penelitian ini untuk menganalisa pegaruh antara kompensasi dan motivasi kerja terhadap kepuasan kerja karyawan. Dengan asumsi bahwa apabila kepuasan kerja karyawan tercapai maka karyawan dapat bekerja maksimal untuk memberikan pelayanan maksimal bagi pelanggan PT PLN (Persero) Unit Layanan Pelanggan Depok Kota Jawa Barat.

\section{TINJAUAN PUSTAKA}

Kompensasi adalah semua pendapatan yang berbentuk uang, barang langsung atau tidak langsung yang diterima karyawan sebagai imbalan atas jasa yang diberikan kepada perusahaan (Hasibun, 2018:118). Salah satu tujuan pemberian kompensasi adalah motivasi. Jika balas jasa yang diberikan cukup besar, manajer akan mudah memotivasi bawahannya.

Menurut (Wangsa, 2016) kompensasi dan motivasi kerja karyawan berpengaruh terhadap kepuasan dan kinerja karyawan, maka dari itu setiap perusahaan harus selalu berusaha agar para karyawannya mempunyai tingkat kepuasan yang tinggi dan kegairahan kerja yang tinggi, sebab apabila perusahaan mampu meningkatkan tingkat kepuasan karyawan maka akan diperoleh banyak keuntungan, pekerjaan akan lebih cepat diselesaikan, kerusakan dapat dikurangi, absensi dapat diperkecil, kemungkinan perpindahan karyawan dapat diperkecil seminimal mungkin, sehingga produktivitas kerja dapat ditingkatkan lebih lagi.

Peran pentingnya akan kompensasi yang sesuai, serta dorongan akan motivasi kerja merupakan salah satu tujuan perusahaan, karena dengan adanya hal itu maka kepuasan kerja dari karyawan akan meningkat. Apabila tingkat kepuasan kerja karyawan meningkat, maka pelayanan terhadap konsumen juga akan memuaskan, sehingga bisa dikatakan bahwa kinerja yang dilakukan oleh para karyawan baik. Namun sebaliknya apabila perusahaan tidak bisa memberikan kompensasi yang sesuai, serta minimnya motivasi kerja seorang karyawan maka akan berdampak negatif terhadap kinerja karyawan.

Ada beberapa pengertian mengenai Motivasi Kerja. Menurut Moon dalam (Busro, 2018:50) mengemukaan bahwa motivasi pegawai sangat efektif untuk meningkatkan dan memenuhi kepuasan kerja pegawai dimana faktor - faktor motivasi tersebut diukur melalui faktor instrinsik (kebutuhan prestasi dan kepentingan) dan faktor ekstrinsik (keamanan kerja, gaji dan promosi).

Menurut Stefan Ivanko dalam (Yusuf, 2018: 132) mendefinisikan motivasi sebagai keinginan dan energi seseorang yang diarahkan untuk pencapaian suatu tujuan. Motivasi adalah sebab dari tindakan. Upaya memengaruhi seseorang dalam rangka memberikan motivasi berarti mendapatkan kemudian inginberbuat sesuatu yang diketahui dan seharusnya dilakukan.

Menurut (Syaifuddin, 2018:57) motivasi menjadikan seseorang berusaha meningkatkan hasil kerja yang ingin dicapai. Timbulnya motivasi karena adanya kebutuhan. Kebutuhan yang mendorong timbulnya motivasi adalah kebutuhan psikologis untuk memenuhi kepuasan fisik seperti makan, minum, oksigen 
dan sebagainya serta kebutuhan sosial psikologis untuk memenuhi kepuasan sosial seperti penghargaan, pujian, rasa aman dan sebagainya.

Menurut Santoso Soroso dalam (Fahmi, 2016) motivasi adalah suatu set atau kumpulan perilaku yang memberikan landasan bagi seseirang untukbertindak dalam suatu acara yang diarahkan kepada tujuan spesifik tertentu (soesific goal directed way)

Menurut Samsudin dalam (Erri \& Fajrin, 2018) motivasi adalah proses memengaruhi atau mendorong dari luar terhadap seseorang atau kelompok kerja agar mereka mau melaksanakan sesuatu yang telah di tetapkan. Menurut Abraham Maslow dalam (Fahmi, 2016) manusia memiliki 5 tingkatan kebutuhan, dimana setiap tingkatan akan diperoleh jika telah dilalui dengan tingkat yang dibawahnya dan seterusnya tingkatan itiu adalah :

\section{Physiological Needs}

Yaitu kebutuhan yang paling dasar yang harus dipenuhi oleh seorang individu. Kebutuhan tersebut mencakup sandang, pangan dan papan. Contohnya kebutuhan makan, minum, perumahan, dan istirahat untuk menjaga kesehatan dan bebas dari rumah sakit.

\section{Safety and Security}

Safety and security yaitu kebutuhan akan perlindungan diri dari Tuhan keamanan dan keselamatan, yaitu kebutuhan bebas dari ancaman (aman dari peristiwa atau lingkungan yang mengancam).

3. Social Needs

Social Needs yaitu kebutuhan akan pertemanan, afiliasi, interaksi, dan cinta. Kebutuhan untuk rasa memiliki (sosial), yaitu kebutuhan untuk diterima oleh kelompok berafiliasi, berinteraksi, dan kebutuhan untuk mencintai serta dicintai.

\section{Esteem Need}

Yaitu kebutuhan untuk dihormati dan di hargai oleh orang lain. Jadi, kebutuhan harga diri yaitu kebutuhan akan diri dan rasa hormat dari orang lain

5. Self-Actualization Needs

Yaitu kebutuhan untuk memenuhi diri sendiri secara maksimal menggunakan kemampuan, keterampilan, dan potensi. Kebutuhan untuk mengaktualisasikan diri, yaitu kebutuhan untuk menggunakan kemampuan skill, dan potensi. Kebutuhan untuk berpendapat dengan mengemukakan ide-ide, gagasan, kritik terhadap sesuatu.

Menurut Mangkubara dalam (Busro, 2018) terdapat beberapa prinsip dalam motivasi kerja karyawan, diantaranya :

1. Prinsip Partisipasi

Dalam upaya memotivasi kerja pegawai perlu diberikan kesempatan ikut berpartisipasi dalam menentukan tujuan yang akan dicapai oleh pemimpin.

2. Prinsip Komunikasi

Pemimpin mengomunikasikan segala sesuatu yang berhubungan dengan usaha pencapaian tugas, dengan informasi yang jelas, pegawai akan lebih mudah di motivasi kerjanya.

3. Prinsip Mengakui Andil Bawahan

Pemimpin mengakui bahwa bawahan (pegawai) mempunyai andil di dalam usaha pencapaian tujuan. Dengan pengakuan tersebut, pegawai akan mudah di motivasi kerjanya.

4. Prinsip Pendelegasian Wewenang

Pemimpin yang memberikan otoritas atau wewenang kepada pegawai bawahan untuk sewaktu-waktu dapat mengambil keputusan terhadap pekerjaan yang dilakukannya, akan membuat pegawai yang bersangkutan menjadi termotivasi untuk mencapai tujuan

5. Prinsip Pemberi Perhatian

Pemimpin memberikan perhatian terhadap apa yang di inginkan oleh pegawai, pegawai bawahan, akan memotivasi pegawai bekerja apa yang di harapkan oleh pemimpin.

Ada beberapa alat-alat dan jenis-jenis dari motivasi sebagai acuan dalam meningkatkan motivasi kerja karyawan.

Menurut (Hasibun, 2018:68) jenis-jenis motivasi yaitu:

1. Motivasi Positif (Intensif Positif) manajer memotivasi bawahan dengan memberikan hadiah kepada mereka yang berprestasi baik. Dengan motivasi positif ini semangat kerja bawahannya akan meningkat, karena 
manusia pada umumnya memang menerima yang baik-baik saja.

2. Motivasi Negatif (Intensif Negatif) manajer memotivasi bawahannya dengan memberikan hukuman kepada mereka yang pekerjaannya kurang baik (prestasi rendah). Dengan memotivasi negatif ini semangat kerja bawahan dalam jangka pendek akan meningkat, karena mereka akan takut dihukum tetapi untuk jangka waktu panjang dapat berakibat kurang baik.

Menurut Handoko dalam (Sutrisno, 2017:75) mengemukakan kepuasan kerja adalah keadaan emosional yang menyenangkan atau tidak menyenangkan bagi para karyawan memandang pekerjaan mereka. Kepuasan kerja mencerminkan perasaan seseorang terhadap pekerjaanya. Ini tampak dalam sikap positif karyawan terhadap pekerjaan dan segala sesuatu yang dihadapi dilingkungan kerjanya. Menurut Steve M. Jex dalam (Sinambela, 2018:302) mendefinisikan bahwa kepuasan kerja sebagai tingkat afeksi positif seorang pekerja terhadap pekerjaan dan situasi pekerjaan, kepuasan kerja berkaitan dengan sikap pekerja atas pekerjaannya. Sikap tersebut berlangsung pada aspek kognitif dan aspek perilaku. Aspek kognitif kepuasan kerja adalah kepercayaan pekerja tentang pekerjaan dan situasi pekerjaan. Menurut Johan dalam (Hartono et al., 2018) menyatakan bahwa kepuasan kerja sebagai respon umum pekerja berupa perilaku yang ditampilkan oleh karyawan sebagai hasil mengenai hal-hal yang berkaitan dengan pekerjaannya. Kepuasan kerja akan didapat apabila ada kesesuaian antara harapan pekerja dengan kenyataan yang ditemui dan didapatkannya dari tempatnya bekerja.

Menurut Vecchio dalam (Braba \& Runanto, 2018) kepuasan adalah kepemikiran, perasaan dan kecenderungan tindakan seseorang yang merupakan sikap seseorang terhadap pekerjaannya. Cara pandang karyawan apakah pekerjaan itu menyenangkan atau tidak menyenangkan. Menurut Handoko dalam (Rahayu \& Pramularso, 2019) kepuasan kerja (Job satisfaction) adalah keadaan emosi yang menyenangkan atau tidak menyenangkan dengan para karyawan memandang pekerjaan mereka. Banyak faktor yang dapat mempengaruhi kepuasan kerja karyawan. Faktor - faktor itu sendiri dalam peranannya memberikan kepuasan kepada karyawan tergantung dengan pribadi masing - masing karyawan. Faktor - faktor yang mempengaruhi kepuasan kerja menurut Gilmer dalam (Sutrisno, 2017) adalah:

\section{Kesempatan Untuk Maju}

Dalam hal ini ada tidaknya kesempatan untuk memperoleh pengalaman dan peningkatan kemampuan selama bekerja.

2. Keamanan Kerja

Faktor ini disebut sebagai penunjang kepuasan kerja, baik bagi karyawan. Keadaan yang aman sangat memengaruhi perasaan karyawan selama kerja.

3. Gaji

Gaji lebih banyak menyebabkan ketidakpuasan, dan jarang orang mengekpresikan kepuasan kerjanya dengan sejumlah uang yang diperolehnya.

4. Perusahaan dan Manajemen

Perusahaan dan manajemen yang baik adalah yang mampu memberikan situasi dan kondisi kerja yang stabil. Faktor ini menentukan kepuasan kerja karyawan.

5. Pengawasan

Sekaligus atasannya, supervisi yang buruk dapat berakibat absensi turn over.

6. Faktor Instrinsik Dari Pekerjaan

Attribute yang ada dalam pekerjaan mensyaratkan keterampilan tertentu. Sukar dan mudahnya serta kebanggaan akan tugas dapat meningkatkan atau mengurangi kepuasan.

7. Kondisi Kerja

Termasuk disini kondisi tempat, ventilasi, penyiaran, kantin, dan tempat parkir.

8. Aspek Sosial Dalam Pekerjaan

Merupakan salah satu sikap yang sulit digambarkan tetapi dipandang sebagai faktor yang menunjang puas atau tidak puas dalam bekerja.

9. Komunikasi

Komunikasi yang lancar antar karyawan dengan pihak manajemen banyak dipakai alasan untuk menyukai jabatannya. Dalam hal ini adanya kesediaan pihak atasan untuk mau mendengar, memahami, dan mengakui pendapat ataupun prestasi karyawannya 
sangat berperan dalam menimbulkan rasa puas terhadap kerja.

10. Fasilitas

Fasilitas rumah sakit, cuti, dana pensiun, atau perumahan merupakan standar suatu jabatan dan apabila dapat dipenuhi akan menimbulkan rasa puas.

Anwar Prabu Mangkunegara dalam (Hamali, 2018) mengemukakan bahwa kepuasan kerja berhubungan dengan variabel - variabel seperti:

\section{Perpindahan Karyawan (Turnover)}

Kepuasan kerja lebih tinggi dihubungkan dengan turnover karyawan yang rendah, sedangkan karyawan yang kurang puas biasanya turnover-nya lebih tinggi.

2. Tingkat Ketidakhadiran (Absen) Kerja

Karyawan yang kurang puas cenderung tingkat ketidakhadirannya (absensi) tinggi. Karyawan sering tidak hadir kerja dengan alasan yang tidak logis dan subjektif,

3. Umur

Ada kencenderungan karyawan yang tua lebih merasa puas daripada karyawan yang berumur relatif muda. Hal ini diasumsikan bahwa karyawan yang tua lebih berpengalaman menyesuaikan diri dengan lingkungan pekerjaan, sedangkan karyawan usia muda biasanya mempunyai harapan yang ideal tentang dunia kerjanya, sehingga apabila antara harapannya dengan realita kekrja terdapat kesenjangan atau ketidakseimbangan dapat menyebabkan karyawan menjadi tidak puas.

4. Tingkat Pekerjaan

Karyawan yang menduduki tingkat pekerjaan yang lebih tinggi cenderung lebih puas daripada karyawan yang menduduki tingkat pekerjaan yang lebih rendah. Karyawan yang tingkat pekerjaannya lebih tinggi menunjukkan kemampuan kerja yang baik dan aktif dalam mengemukakan ide ide serta kreatif dalam bekerja.

5. Ukuran Organisasi Perusahaan

Ukuran organisasi perusahaan dapat memengaruhi kepuasan karyawan, hal ini karena besar kecil suatu perusahaan berhubungan pula dengan koordinasi, komunikasi, dan partisipasi karyawan.
Ada beberapa hal yang menjadi penyebab kepuasan kerja Menurut Kreitner dan Knicki dalam (Wibowo, 2017) terdapat lima faktor yang dapat memengaruhi timbulnya kepuasan kerja, yaitu sebagai berikut:

\section{Need Fulfilment (Pemenuhan Kebutuhan)} Model ini dimaksudkan bahwa kepuasan kerja ditentukan oleh tingkatan karakteristik pekerjaan memberikan kesempatan pada individu untuk memenuhi kebutuhannya.

2. Discrepancies (Perbedaan)

Model ini menyatakan bahwa kepuasan merupakan suatu hasil memenuhi harapan. Pemenuhan harapan mencerminkan perbedaan antara apa yang diharapkan dan diperoleh individu dari pekerjaan. Apabila harapan lebih besar daripada apa yang diterima, orang akan tidak puas. Sebaliknya diperkirakan individu akan puas apabila mereka menerima manfaat di atas harapan.

3. Value Attainment (Pencapaian Nilai)

Gagasan value attainment adalah bahwa kepuasan merupakan hasil dari persepsi pekerjaan memberikan pemenuhan nilai kerja individual yang penting.

4. Equity (Keadilan)

Dalam model ini dimaksudkan bahwa kepuasan merupakan fungsi dari seberapa adil individu diperlakukan di tempat kerja. Kepuasan merupakan hasil persepsi orang bahwa perbandingan antara hasil kerja dan inputnya relatifnya lebih menguntungkan dibandingkan dengan dengan perbandingan antara keluaran dan masukkan pekerjaan lainnya.

5. Dispositional Compements (Komponen Genetik)

Beberapa rekan kerja atau teman tampak puas terhadap variasi lingkungan kerja, sedangkan lainnya kelihatan tidak puas. Model ini didasarkan pada keyakinan bahwa kepuasan kerja sebagian merupakan fungsi sifat pribadi dan faktor genetic. Model menyiratkan perbedaan individu hanya mempunyai arti penting untuk menjelaskan kepuasan kerja seperti hasilnya karakteristik lingkungan pekerjaan.

Hubungan antara kepuasan kerja dengan variabel lain dapat bersifat positif dan negatif. Kekuatan hubungan mempunyai rentang dari 
lemah sampai kuat. Hubungan yang kuat menunjukkan manajer dapat memengaruhi dengan signifikan variabel lainnya dengan meningkatkan kepuasan kerja. Menurut Kritner dan Knicki (Wibowo 2017) beberapa korelasi kepuasan kerja adalah sebagai berikut

\section{Motivation (Motivasi)}

Penelitian ini menunjukkan bahwa terdapat hubungan positif dan signifikan antatra motivasi dengan kepuasan kerja. Karena kepuasan dengan supervisi juga mempunyai korelasi signifikan dengan motivasi, manajer disarankan mempertimbangkan bagaimana perilaku mereka memengaruhi kepuasan pekerja. Manajer secara potensial dapat meningkatkan motivasi pekerja melalui berbagai usaha untuk meningkatkan kepuasan kerja.

\section{Job Development (Pelibatan Kerja)}

Pelibatan kerja menunjukkan kenyataan di mana individu secara pribadi dilibatkan dengan peran kerjanya. Penelitian menunjukkan bahwa pelibatan kerja mempunyai huubungan moderat dengan kepuasan kerja. Untuk itu manajer didorong memperkuat lingkungan kerja yang memuaskan untuk mendorong keterlibatan kerja pekerja.

\section{Organizational Citizenship Behavior}

Merupakan perilaku pekerja di luar dari apa yang menjadi tugasnya. Sebagai contoh adalah adanya bisik-bisik sebagai pernyataan kostruktif tentang departemen, ekspresi tentang perhatian pribadi atas pekerjaan orang lain, saran untuk perbaikan, melatih orang baru, menghargai semangat, perhatian terhadap kekayaan organisasi dan kehadiran di atas standar yang ditentukan. Organizational citizenship behavior lebih banyak ditentukan oleh kepemimpinan dan karakteristik lingkungan kerja daripada oleh keperibadian pekerja.

4. Organizational Commitment (Komitmen Organisasional)

Komitmen organisasional mencerminkan tingkatan dimana individu mengidentifikasi dengan organisasi dan mempunyai komitmenterhadap tujuannya. Penelitian menunjukkan bahwa terdapat huubungan signifikan dan kuat antara komitmen organisasi dan kepuasan. Manajer disarankan meningkatkan kepuasan kerja dengan maksud untuk menimbulkan tingkat komitmen yang lebih tinggi. Selanjutnya, komitmen yang lebih tinggi dapat memfasilitasi produktivitas lebih tinggi.

5. Absenteeism (Kemangkiran)

Kemangkiran merupakan hal mahal dan manajer secara tetap mencari cara untuk menguranginya. Satu rekomendasi telah meningkatkan kepuasan kerja. Apabila rekomendasinya sah, akan terdapat korelasi negative yang kuat antara kepuasan dan kemangkiran. Dengan kata lain, apabila kepuasan meningkat, kemangkiran akan turun. Penelitian yang pernah dilakukan menunjukkan terdapat hubungan negatif yang lemah antara kepuasan dan kemangkiran. Oleh karena itu, manajer akan menyadari setiap penurunan signifikan dalam kemangkiran akan meningkatkan kepuasan kerja.

Karakteristik individu yang dimiliki seorang pegawai, pemberian remunerasi, dan karakteristik pekerjaan yang dijalankan pegawai merupakan unsur penting dalam mencapai kerja yang optimal. Namun tiga usnur tersebut pada hakikatnya untuk memgangun motivasi kerja, sehingga dengan motivasi kerja yang tinggi akan menjamin pencapaian kerja yang diharapkan.

\section{Kerangka Pemikiran}

Hal yang menarik untuk diteliti dan dikaji berikut ini adalah mengenai kompensasi dan motivasi kerja terhadap kepuasan kerja pada PT PLN . Penelitian ini dapat memaksimalkan keberadaan PT PLN di tengah-tengah masyarakat. Berdasarkan hal tersebut, maka langkah awal dalam penelitian adalah membuat model penelitian melaui kerangka pemikiran, seperti pada gambar 1 .

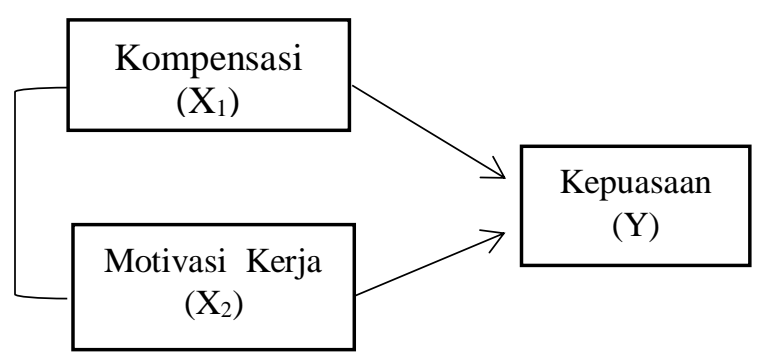

Gambar 1. Model Penelitian 
Berdasarkan kerangka pemikiran diatas, selanjutnya dirumuskan hipotesis penelitian yaitu: (1) $\mathrm{H} 1=$ diduga Kompensasi karyawan PT Pln (Persero) Unit Layanan Pelanggan Depok Kota Jawa Barat, berpengaruh secara positif dan signifikan terhadap Kepuasan kerja karyawan; (2) $\mathrm{H} 2=$ diduga motivasi kerja karyawan PT Pln (Persero) Unit Layanan Pelanggan Depok Kota Jawa Barat berpengaruh secara positif dan signifikan terhadap Kepuasan kerja karyawan.

\section{METODE PENELITIAN}

Data yang digunakan adalah data primer dengan teknik pengumpulan data yang dilakukan yaitu: (1) kuesioner;(2) wawancara (Interview), dan (3) observasi. Penelitian ini dilakukan pada bulan April sampai dengan Juni 2019. Hasil Kuisioner ini diolah menggunakan SPSS (Statistical Product and service Solution). Populasi merupakan keseluruhan dari objek atau subjek ataupun individu pada suatu wilayah yang akan diteliti (Hamid \& Patra, 2019). Adapun populasi yang digunakan didalam penelitian ini yaitu PT PLN (Persero) Unit Layanan Pelanggan Depok Kota Jawa Barat. Sampel merupakan bagian dari populasi yang terpilih dengan prosedur tertentu yang dapat merepresentasikan populasi (Hamid \& Patra, 2019). Pada penelitian ini penulis menyebarkan kuesioner kepada responden sebanyak 51 orang sebagai sampel dengan teknik pengambilan sampel jenuh atau sampling total sehingga semua anggota populasi digunakan sebagai sampel. Penelitian dihitung dengan tingkat kesalahan 0.05. Untuk mengetahui analisis dari Kompensasi dan motivasi kerja terhadap Kepuasan kerja karyawan maka penulis menggunakan persamaan regresi dan anova.

\section{HASIL PENELITIAN DAN PEMBAHASAN}

Pada tahun 1972, sesuai dengan Peraturan Pemerintah No. 17, status Perusahaan Listrik Negara (PLN) ditetapkan sebagai Perusahaan Umum Listrik Negara dan sebagai Pemegang Kuasa Usaha Ketenagalistrikan (PKUK) dengan tugas menyediakan tenaga listrik bagi kepentingan umum.
Seiring dengan kebijakan Pemerintah yang memberikan kesempatan kepada sektor swasta untuk bergerak dalam bisnis penyediaan listrik, maka sejak tahun 1994 status PLN beralih dari Perusahaan Umum menjadi Perusahaan Perseroan (Persero) dan juga sebagai PKUK dalam menyediakan listrik bagi kepentingan umum hingga sekarang.

\section{Uji Korelasi}

Penelitian ini dilakukan dengan cara menyebar kuesioner kepada seluruh karyawan PT Pln (Persero) Unit Layanan Pelanggan Depok Kota Jawa Barat yang berjumlah 51 orang. Hasil penelitian menghasilkan nilai $\mathrm{R}$ square sebesar 0,812 , yang mengindikasikan bahwa kepuasan kerja karyawan dipengaruhi oleh kompensasi dan motivasi kerja sebesar $81,2 \%$ sedangkan sisanya $18,8 \%$ dipengaruhi oleh faktor-faktor lain di luar kedua varibel tersebut. Dihasilkan pula nilai-nilai statistik yang digunakan dalam membentuk persamaan regresi seperti pada tabel 1. Berdasarkan perhitungan persamaan regresi menggunakan SPSS, sebagai berikut:

\section{Tabel 1}

\section{Koefisien Korelasi}

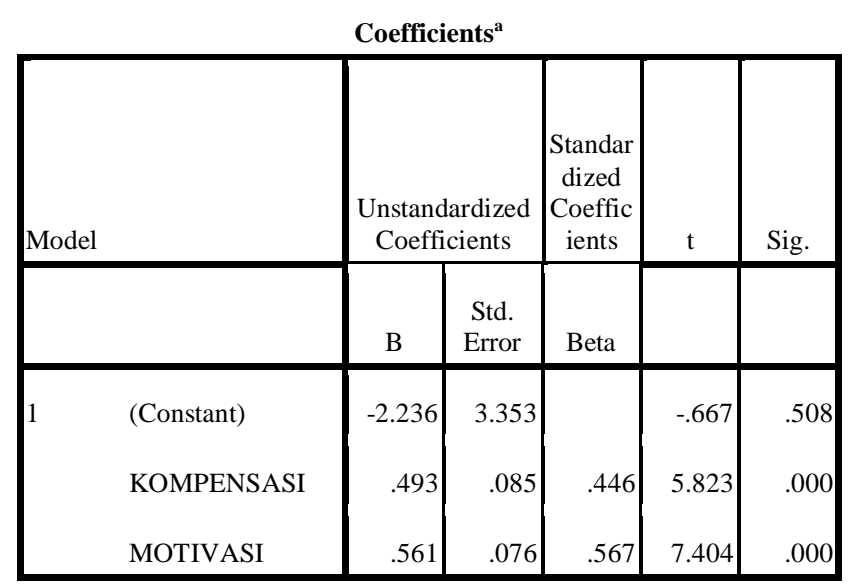

Berdasarkan data diatas maka persamaan regresi untuk penelitian ini yaitu : $\mathrm{Y}=-2.236+$ $0,493 \mathrm{X} 1+0,561 \mathrm{X} 2+\mathrm{e}$. Hal ini menunjukkan setiap peningkatan satu unit kompensasi maka kepuasan kerja akan meningkatkan sebesar 0,493 dan setiap peningkatan satu unit motivasi kerja maka kepuasan kerja akan meningkat sebesar 0,561 .

\section{Uji Simultan}

Selanjutnya adalah melakukan Uji pengaruh simultan. Uji simultan ini dilakukan untuk 
mengetahui apakah variabel independen secara bersama-sama atau simultan mempengaruhi variabel dependen.

\section{Tabel 2}

\section{Uji Simultan}

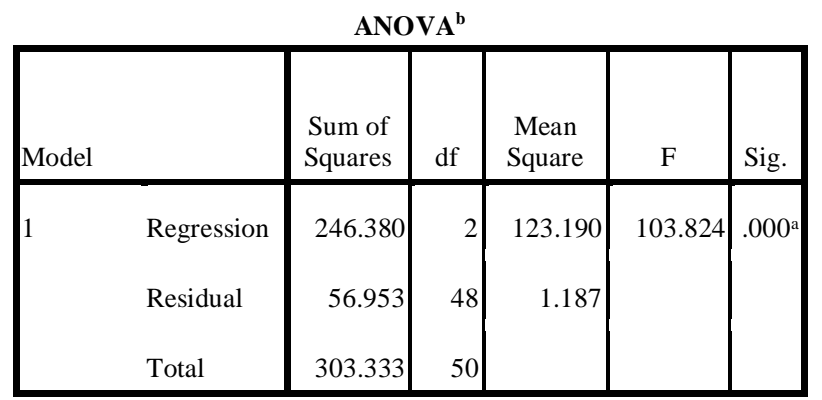

Uji ini dapat dilihat pada nilai $\mathrm{F}$ test sebesar 103,824 (pada Tabel.2) dan signifikan pada 0.000 yang berarti variabel independen kompensasi dan motivasi kerja secara simultan mempengaruhi variabel kepuasan kerja karyawan.

\section{SIMPULAN}

Hasil uji ini menjawab hipotesis penelitian bahwa HA diterima, dimana Fhit > Ftabel dan sig < 0,05. Hal ini berarti bahwa kompensasi dan motivasi kerja karyawan secara simultan berpengaruh positif dan signifikan terhadap kepuasan kerja karyawan. Seorang karyawan yang memiliki kompensasi kerja yang baik dan memiliki motivasi kerja yang tinggi maka akan meningkatkan kepuasan dalam bekerja.

Akan tetapi hal ini hanya beberapa factor saja yang diteliti. Maka untuk penelitian selanjutnya dapat dilakukan penelitian dengan menambahkan faktor lain untuk dapat mengetahu hal-hal lain yang berpengaruh terhadap kepuasan bekerja karyawan.

\section{DAFTAR PUSTAKA}

Braba, R., \& Runanto, D. (2018). pengaruh gaya kepemimpinan terhadap kepuasan kerja dengan motivasi kerja sebagai variabel. O(0), 1-18.

Busro, M. (2018). Teori-Teori Manajemen Sumber Daya Manusia. jakarta: Prenadamedia.

Edy, S. (2017). Manajemen Sumber Daya Manusia. Jakarta: KENCANA PRENADAMEDIA GROUP.
Erri, D., \& Fajrin, A. N. (2018). Pengaruh Motivasi Kerja Terhadap Kinerja Karyawan Pada PT Media Intan Semesta Jakarta. XVI(1), 77-83.

Fahmi, I. (2016). Perilaku Organisasi. Bandung: Alfabeta, CV.

Hamid, R. S., \& Patra, I. K. (2019). PENGANTAR STATISTIKA UNTUK RISET BISNIS DAN EKONOMI Konsep Dasar dan Aplikasi SPSS versi 25. Banten: CV. AA. RIZKY.

Hamali, A. Y. (2018). Pemahaman Manajemen Sumber Daya Manusia. Jagakarsa: PT Buku Seru.

Hartono, A., Anwar, S., Susila, A. D., Sabiham, S., Program, A. S., Utara, A., \& Resource, L. (2018). Pengaruh Gaya Kepemimpinan Dan Motivasi Kerja Terhadap Kinerja Guru Melalui Kepuasan Kerja Pada SMK Negeri 5 Jember. O(1), 515-526.

Hasibun, M. S. . (2018). Manajemen Sumber Daya Manusia. Jakarta: PT Bumi Aksara.

Rahayu, G., \& Pramularso, E. Y. (2019). Pengaruh Kompensasi terhadap Kepuasan Kerja Pegawai Bagian SDM \& Umum PT KAI Daerah Operasi 1 Jakarta. 17, 1-6.

Sinambela, L. P. (2018). Manajemen Sumber Daya Manusia. Jakarta: PT Bumi Aksara.

Syaifuddin. (2018). Motivasi Dan Kinerja Pegawai Pendekatan Riset. Sidoarjo: Indomedia Pustaka.

Wangsa, R. C. (2016). Pengaruh kompensasi dan motivasi kerja terhadap kepuasan kerja karyawan serta dampaknya pada kinerja karyawan (studi kasus pada pt. Daun kencana sakti). Agora, 4(1), 710719. Retrieved from http://publication.petra.ac.id/index.php/ manajemenbisnis/article/viewFile/6715/6085

Wibowo. (2017). Manajemen Kinerja. Depok: PT Rajagrafindo Persada. 
Yusuf, H. A. (2018). Pemahaman Manajemen Sumber Daya Manusia Strategi Mengelola Karyawan. Yogyakarta: CAPS (Center for Academic Publishing Service). 